This is the final peer-reviewed accepted manuscript of:

Gianluca Allegro, Ana B. Bautista-Ortín, Encarna Gómez-Plaza, Chiara Pastore, Gabriele Valentini, Ilaria Filippetti

Impact of Flavonoid and Cell Wall Material Changes on Phenolic Maturity in cv.

Merlot (Vitis vinifera L.)

which has been published in final form in Am J Enol Vitic. October 2018 69: 417-421;

DOI: $\underline{10.5344 / a j e v .2018 .18011}$

C2018 by the American Society for Enology and Viticulture

Licensing information:

https://www.ajevonline.org/content/open-access-and-subscription-publishing-options 


\title{
Impact of Flavonoid and Cell Wall Material Changes on Phenolic Maturity in cv. Merlot (Vitis vinifera L.)
}

\author{
Gianluca Allegro, ${ }^{1}$ Ana B. Bautista-Ortín, ${ }^{2}$ Encarna Gómez-Plaza, ${ }^{2}$ \\ Chiara Pastore, ${ }^{1}$ Gabriele Valentini, ${ }^{1}$ and Ilaria Filippetti ${ }^{1 *}$
}

\begin{abstract}
In black berry varieties, the changes in flavonoid concentration and composition that occur in the last weeks before harvest only partially explain the improved sensory attributes linked with the progression of ripening. To better understand the factors involved in phenolic maturity of cv. Merlot, total and extractable anthocyanins and tannins were analyzed during late ripening, and the properties of skin cell wall material were determined. Over two consecutive years, both total and extractable anthocyanins increased until harvest, while minor variations in tannin concentration were found. A greater affinity of cell wall material for a commercial seed tannin was observed in the last ripening phases, preferentially involving high molecular mass tannins and galloylated forms. The increased anthocyanins could allow a more highly colored wine to be obtained with the progression of ripening, and the increasing affinity of skin cell wall material for seed tannins may play a role in the reduction of astringency. This research shows how different factors could influence phenolic maturity, confirming the original insights in Merlot.
\end{abstract}

Key words: anthocyanin, berry composition, cell wall material, grape ripening, phenolic maturity, tannin

Berry flavonoids accumulate in different phenological phases. Flavan-3-ol monomers and proanthocyanidins, commonly called tannins, are synthesized in the skins and seeds from the early stages of berry development, while anthocyanins only appear in the skin at veraison. Genotype, temperature, sunlight exposure, and water availability are just a few of the factors that affect the evolution of berry flavonoids during ripening, and since many of these factors are seasondependent, the concentration and composition of these compounds can vary strongly among years (Downey et al. 2006).

Both the concentration and the extractability of anthocyanins and tannins from berry tissues in which they are stored are key determinants of wine phenolic profile. Previous research examining the changes in extractability during ripening has produced conflicting results. The extractability of Tempranillo and Sangiovese anthocyanins increased with the progression of maturity (Hernández-Hierro et al. 2012, Allegro et al. 2016), but no difference was found for Shiraz (Fournand et al. 2006). The extractability of seed tannins was also variety-dependent: Pinot noir seed tannins became easier to extract approaching harvest (Pastor Del Rio and Kennedy 2006), while fewer Monastrell seed tannins could be extracted with a solution containing $12.5 \%$ ethanol during ripening (Bautista-Ortín et al. 2012).

${ }^{1}$ Dipartimento di Scienze Agrarie, Università di Bologna, viale Fanin 44, 40127, Bologna, Italy; and ${ }^{2}$ Departamento de Tecnología de Alimentos, Nutrición y Bromatología, Universidad de Murcia, Campus de Espinardo, 30071, Murcia, Spain. *Corresponding author (ilaria.filippetti@unibo.it; fax +390512096400)

Acknowledgments: This research was partially funded by the $\mathrm{PhD}$ program of the University of Bologna. The authors declare no competing financial interest. The authors thank Mrs. Emilia Colucci for her technical assistance.
Recent interest has focused on the characteristics and properties of cell wall material (CWM) of berry skin and flesh, because the interactions between this material and berry flavonoids may affect the concentration, composition, and extractability of anthocyanins and tannins in the resulting wine (Bautista-Ortín et al. 2016a). Anthocyanins and tannins can bind to CWM via hydrogen bonds and hydrophobic interaction (Le Bourvellec et al. 2004), and as these associations precipitate during vinification, they could reduce the phenolic content of wine (Bindon et al. 2010a). This effect is variety-specific: Monastrell pomace CWM removed more tannins than that of Cabernet Sauvignon and Syrah (Bautista-Ortín et al. 2015).

Moreover, interactions of flavonoids with cell walls may change the composition of the remaining flavonoids. Shiraz $\mathrm{CWM}$ had a preference for the galloylated forms of seed proanthocyanidins (Bindon et al. 2010a), while Monastrell skin CWM did not (Bautista-Ortín et al. 2014). These latter authors reported that interactions between grape CWM and proanthocyanidins are favored by higher molecular mass proanthocyanidins, which are considered responsible for wine astringency (Vidal et al. 2003).

There was no variation in the concentration and composition of extractable tannins reported during late ripening (Allegro et al. 2016), in contrast with an astringency decrease reported with the progression of ripening (Llaudy et al. 2008), given that tannins are involved in this oral sensation.

This research examined the mechanisms driving phenolic maturity by analyzing berry flavonoid compounds and their interactions with CWM during late ripening. The investigation was conducted on Merlot grape, which is one of the most frequently cultivated varieties in the world. 


\section{Materials and Methods}

Plant material and yield components. The study was conducted in 2014 and 2015, in a 12-year-old irrigated vineyard of Vitis vinifera L. cv. Merlot (clone R3 grafted onto SO4 rootstock) located in Valsamoggia, Bologna, Italy $\left(44^{\circ} 28^{\prime} \mathrm{N}\right.$; $\left.11^{\circ} 07^{\prime} \mathrm{E}\right)$. Vines were spaced $1 \mathrm{~m}$ within the row and $3 \mathrm{~m}$ between rows, and were trained to a vertically shoot-positioned (VSP) spur-pruned cordon. Shoots were trimmed twice, in June and July, and pest management was performed according to Emilia-Romagna Region standard practices.

Weather data. Weather data were kindly provided by the meteorological service of Emilia-Romagna Region (ARPAE), which operates a meteorological station near the vineyard.

Berry sampling. Along two adjacent rows of $\sim 150 \mathrm{~m}$, four replicates of five vines each were established to adequately represent spatial variability. A random sample of 130 berries was collected from each replicate (520 berries for each sampling date from full veraison to harvest) by cutting through the pedicel with scissors. Each sample was divided into five subsamples for the following determinations: a) must chemical parameters ( 25 berries); b) total anthocyanins ( 20 berries); c) extractable anthocyanins and tannins (40 berries); d) total tannins (20 berries); and e) skin CWM composition and properties ( 25 berries). The berry subsamples for the determination of must chemical parameters were processed immediately, while the others were frozen and stored at $-20^{\circ} \mathrm{C}$.

Analysis of flavonoids and CWM properties was performed on the last three sampling dates, all during the last 20 days before harvest, on the following dates: 18 Sept (47 days after veraison; DAV), 29 Sept (58 DAV), and 7 Oct (66 DAV) in 2014, and 27 Aug (26 DAV), 7 Sept (37 DAV), and 16 Sept (46 DAV) in 2015. The harvest date was decided each year according to the winery procedure for Merlot winemaking. We considered it both relevant and practical to get information about grape phenolic maturity close to harvest in two seasons with different weather conditions and ripening trends.

Must chemical analysis. Must soluble solids concentration was determined using a temperature-compensating Maselli R50 refractometer (Maselli Misure). Must $\mathrm{pH}$ and titratable acidity were measured using a Crison Titrator (Crison Instruments).

Extraction of anthocyanins and tannins using a model hydroalcoholic solution. Skins were peeled from frozen berries and seeds were separated from the mesocarp, then soaked separately and shaken daily in tubes containing $80 \mathrm{~mL}$ hydroalcoholic solution for 15 days at $28^{\circ} \mathrm{C}$ (Allegro et al. 2016). The hydroalcoholic solution contained $6 \mathrm{~g} / \mathrm{L}$ tartaric acid, 40 $\mathrm{mL} / \mathrm{L} 1 \mathrm{~N} \mathrm{NaOH}, 100 \mathrm{mg} / \mathrm{L}$ potassium metabisulfite, and a proportion of ethanol that was raised from 0 to $13 \%$ in the first 12 days of extraction.

Exhaustive extraction of anthocyanins and tannins. Total anthocyanins were extracted by soaking the peeled skins in $100 \mathrm{~mL}$ methanol for $24 \mathrm{hr}$ (Mattivi et al. 2006). Total tannins were extracted from the skins and seeds were ground separately to a fine powder before extracting $1 \mathrm{mg}$ of the sample in $1 \mathrm{~mL} 70 \%(\mathrm{v} / \mathrm{v})$ acetone in water, for $24 \mathrm{hr}$ in the dark (Downey et al. 2003).
Anthocyanin and tannin determinations. Total and extractable anthocyanins and tannins were separated by high-performance liquid chromatography (HPLC) using a Waters 1525 instrument equipped with a diode array detector and a reversed-phase column (RP18 $250 \times 4 \mathrm{~mm}, 5$ $\mu \mathrm{m})$ with a pre-column (Phenomenex). The concentration of anthocyanins was determined as described (Mattivi et al. 2006). The tannin content was determined by acid-catalyzed cleavage in the presence of excess phloroglucinol (Kennedy and Jones 2001). The separation of monomer subunits and cleaved proanthocyanidins was done using two different published HPLC methods (Downey et al. 2003). One analysis per sample was performed for each determination, without an analytical replicate.

Skin CWM preparation and binding reaction with a commercial seed tannin. The four subsamples collected on each sampling date for skin CWM analysis were combined and CWM was isolated as described (De Vries et al. 1981). Lyophilized skins were ground to a fine powder and $5 \mathrm{~g}$ was suspended in $10 \mathrm{~mL}$ boiling water for $5 \mathrm{~min}$ then homogenized. One part of the homogenized material was mixed with two parts $96 \%$ ethanol and extracted for $30 \mathrm{~min}$ at $40^{\circ} \mathrm{C}$. The material was separated by centrifugation and extracted again with fresh $70 \%$ ethanol for $30 \mathrm{~min}$ at $40^{\circ} \mathrm{C}$. The washing treatment with fresh $70 \%$ ethanol was repeated eight times to remove soluble solids. The alcohol insoluble solids were then washed once with $96 \%$ ethanol, twice with acetone, then dried overnight under an air stream at room temperature.

The interactions between CWM and proanthocyanidins were studied using Merlot skin CWM from both seasons combined with a seed enological tannin (TanReactive, Agrovin S.A.), as described (Castro-López et al. 2016). Briefly, CWM samples were combined with the enological tannin previously dissolved in a model solution (12\% ethanol and $\mathrm{pH} 3.6$ adjusted with trifluoroacetic acid) at a concentration of $2 \mathrm{~g} / \mathrm{L}$. The reaction volume was $2.5 \mathrm{~mL}$ and the final CWM concentration was $13 \mathrm{mg} / \mathrm{mL}$. The samples were shaken at $300 \mathrm{rpm}$ in an orbital shaker at room temperature for $90 \mathrm{~min}$.

After the binding reactions, the recovered tannins were analyzed by HPLC as described (Downey et al. 2003), and by size exclusion chromatography (SEC) as described (Kennedy and Taylor 2003) with modifications (Castro-López et al. 2016). The method used two PLgel $(300 \times 7.5 \mathrm{~mm}, 5$ $\mu \mathrm{m}), 500 \times 100 \AA$ columns connected in series and protected by a guard column containing the same material $(50 \times 7.5$ $\mathrm{mm}, 5 \mu \mathrm{m}$ ), all purchased from Polymer Labs. The amount of sample injected was $40 \mu \mathrm{g}$. The isocratic method used a mobile phase consisting of N,N-dimethylformamide containing $1 \%$ glacial acetic acid, $5 \%$ water, and $0.15 \mathrm{M}$ lithium chloride. The flow-rate was maintained at $1 \mathrm{~mL} / \mathrm{min}$ with a column temperature of $60^{\circ} \mathrm{C}$, and elution was monitored at $280 \mathrm{~nm}$. Four analytical replicates were performed for each described determination.

Statistical analysis. Data were subjected to longitudinal data analysis using the mixed procedure available in SAS v9.0 (SAS Institute, Inc.), with compound symmetric (cs) as covariance structure (Brunner et al. 2012). 


\section{Results and Discussion}

Climate data, sugar concentration, and berry development. The period from July to September was cool and rainy in 2014, but in the same period of the following year, the average temperature was $2.5^{\circ} \mathrm{C}$ higher, and rainfall was reduced by $\sim 73 \%$ (Supplemental Table 1). As a result, the progression of ripening during the last 20 days before harvest was much slower in 2014 than in 2015. This difference is evident in that sugar concentration $\sim 46$ to $47 \mathrm{DAV}$ was 4 Brix lower in 2014 than in 2015 (Table 1). In 2015, sugar concentration rose by $\sim 3$ Brix without a dehydration effect, since no change in berry weight was recorded. Young leaves could have maintained high levels of photosynthetic activity also after 30 to 50 DAV (Gatti et al. 2016), and this could have promoted intense soluble solids accumulation until harvest. On the contrary, in 2014, the sugar concentration increase was small due to unfavorable weather.

The weights of berry, skin, and seed did not change in 2014, but in the second year, skin weight increased and with it, the skin-to-berry weight ratio.

Anthocyanin and tannin analysis. In both years of the study, the level of both total and extractable anthocyanins

Table 1 Soluble solids concentration and mean weights of berry, skin, and seed during ripening in 2014 and 2015.

\begin{tabular}{lcccc}
\hline $\begin{array}{l}\text { Days after } \\
\text { veraison }\end{array}$ & $\begin{array}{c}\text { Soluble } \\
\text { solids } \\
\text { (Brix) }\end{array}$ & $\begin{array}{c}\text { Berry wt } \\
\text { (g) }\end{array}$ & $\begin{array}{c}\text { Skin wt } \\
\text { (g/berry) }\end{array}$ & $\begin{array}{c}\text { Seed wt } \\
\text { (g/berry) }\end{array}$ \\
\hline $47(2014)$ & $21.6 \mathrm{~b}^{\mathrm{a}}$ & 2.60 & 0.290 & 0.103 \\
$58(2014)$ & $22.0 \mathrm{ab}$ & 2.58 & 0.297 & 0.104 \\
$66(2014)$ & $22.2 \mathrm{a}$ & 2.47 & 0.276 & 0.102 \\
Significance & $*$ & $\mathrm{~ns}$ & $\mathrm{~ns}$ & $\mathrm{~ns}$ \\
$26(2015)$ & $22.7 \mathrm{~b}$ & 1.98 & $0.269 \mathrm{~b}$ & 0.083 \\
$37(2015)$ & $25.1 \mathrm{a}$ & 1.94 & $0.322 \mathrm{a}$ & 0.090 \\
$46(2015)$ & $25.6 \mathrm{a}$ & 1.96 & $0.327 \mathrm{a}$ & 0.096 \\
Significance & $*$ & $\mathrm{~ns}$ & $*$ & $\mathrm{~ns}$ \\
\hline
\end{tabular}

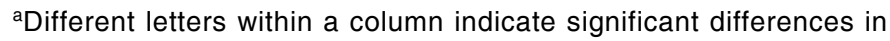
each year.

${ }^{\mathrm{b}}$ Asterisks indicate significance at $p<0.05$; ns, not significant. increased during the last ripening phases (Table 2). The rise in extractable anthocyanins in 2014 was proportional with that of total anthocyanins, while in 2015, extractable anthocyanins increased their proportion of total anthocyanins. The more intense growth in the second year was probably due to the increased skin-to-berry ratio that could have facilitated the extraction of these compounds. Skin tannins showed no clear trend, but their concentration is affected by factors such as variety, cultural practices, and environmental conditions (Fournand et al. 2006, Hernández-Hierro et al. 2012, Bindon et al. 2014).

In the last ripening phases (20 days before harvest), total and extractable seed tannins showed only minor variations, as previously reported (Pastor del Rio and Kennedy 2006). In Merlot seed tannin, oxidative crosslinking of polymers and formation of branched polymers more resistant to hydrolysis, which have been linked to decreased seed tannins after veraison (Downey et al. 2003, Cadot et al. 2006), had negligible effects in the last 20 days of ripening.

The mean degree of polymerization (mDP) of the total tannin was greater than that of the extractable portion, as reported previously (Allegro et al. 2016). The difference in mDP values is probably due to the greater extraction efficiency of acetone than of hydroalcoholic solution (Pastor Del Rio and Kennedy 2006, Bautista-Ortín et al. 2012). No change in mDP was observed in the last phase of ripening, probably because tannin composition does not undergo important variations during this period. Similar results were found in a study of six varieties: on the last two sampling dates, performed when berries reached 16 and 20 Brix, respectively, no change was observed in skin and seed tannin mDP (Bordiga et al. 2011).

Interactions of CWMs with enological seed tannin. Phloroglucinolysis analysis showed that during the last ripening phases, skin CWM increased its affinity for commercial seed tannin, as the tannins remaining in solution decreased significantly until the point of harvest (Table 3). CWM preferentially adsorbed tannin with higher mDP and galloylated forms, since the average $\mathrm{mDP}$ and percentage of galloylation of the tannins remaining in solution after the interactions was lower than that

Table 2 Total and extractable anthocyanins, skin, and seed tannins during ripening in 2014 and 2015.

\begin{tabular}{|c|c|c|c|c|c|c|c|c|c|c|}
\hline \multirow[b]{2}{*}{$\begin{array}{l}\text { Days after } \\
\text { veraison }\end{array}$} & \multicolumn{5}{|c|}{ Total } & \multicolumn{5}{|c|}{ Extractable } \\
\hline & $\begin{array}{c}\text { Anthocyanins } \\
\text { (mg/kg of } \\
\text { berries) }\end{array}$ & $\begin{array}{c}\text { Skin } \\
\text { tannins } \\
\text { (mg/kg } \\
\text { berries) }\end{array}$ & $\begin{array}{c}\text { Skin } \\
\text { tannin } \\
\text { mDPa }\end{array}$ & $\begin{array}{c}\text { Seed } \\
\text { tannins } \\
\text { (mg/kg } \\
\text { berries) }\end{array}$ & $\begin{array}{c}\text { Seed } \\
\text { tannin } \\
\text { mDP }\end{array}$ & $\begin{array}{l}\text { Anthocyanins } \\
\text { (mg/kg berries) }\end{array}$ & $\begin{array}{c}\text { Skin } \\
\text { tannins } \\
\text { (mg/kg } \\
\text { berries) }\end{array}$ & $\begin{array}{c}\text { Skin } \\
\text { tannin } \\
\text { mDP }\end{array}$ & $\begin{array}{c}\text { Seed } \\
\text { tannins } \\
\text { (mg/kg } \\
\text { berries) }\end{array}$ & $\begin{array}{c}\text { Seed } \\
\text { tannin } \\
\text { mDP }\end{array}$ \\
\hline 47 (2014) & $1035 b^{b}$ & $873 b$ & 9.31 & 1634 & 7.23 & $391 \mathrm{~b}$ & $379 \mathrm{~b}$ & 6.20 & 776 & 4.66 \\
\hline $58(2014)$ & $1141 \mathrm{a}$ & $1002 \mathrm{a}$ & 9.69 & 1700 & 6.38 & $377 \mathrm{~b}$ & $429 a$ & 7.22 & 780 & 4.36 \\
\hline 66 (2014) & $1122 \mathrm{a}$ & $911 a b$ & 9.95 & 1689 & 6.90 & $432 \mathrm{a}$ & $438 \mathrm{a}$ & 6.23 & 805 & 4.69 \\
\hline Significance ${ }^{c}$ & * & * & ns & ns & ns & * & * & ns & ns & ns \\
\hline $26(2015)$ & $1606 \mathrm{~b}$ & 1016 & 8.46 & 1721 & 4.93 & $481 \mathrm{~b}$ & 474 & 5.33 & 1142 & 4.13 \\
\hline 37 (2015) & $1781 \mathrm{a}$ & 1010 & 7.58 & 1855 & 5.65 & $519 \mathrm{~b}$ & 449 & 5.77 & 1140 & 4.19 \\
\hline $46(2015)$ & $1796 \mathrm{a}$ & 995 & 7.30 & 1848 & 5.59 & $592 \mathrm{a}$ & 480 & 5.65 & 1087 & 4.21 \\
\hline Significance & * & ns & ns & ns & ns & * & ns & ns & ns & ns \\
\hline
\end{tabular}

${ }^{a} \mathrm{mDP}$, mean degree of polymerization.

${ }^{b}$ Different letters within a column indicate significant differences in each year.

${ }^{c}$ Asterisks indicate significance at $p<0.05 ;$ ns, not significant. 
of the original. These results showed the ability of CWM to remove increasing quantities of tannin with the progression of ripening, and in particular, those forms more involved in the perception of astringency (Vidal et al. 2003).

The SEC analysis confirmed that CWM preferentially adsorbed proanthocyanidins of high molecular weight (those whose maximum appear at lower retention times in the SEC graph, Figure 1) and strengthened the phloroglucinolysis results. CWM interacts selectively with high molecular mass proanthocyanidins (Bindon et al. 2010a, Bautista-Ortín et al. 2016b) because the number of reactive sites that allow binding increases with the dimension of the proanthocyanidin (Haslam 1998). Cell walls from 2015 grapes also retained important quantities of medium molecular weight proanthocyanidins, while not all or only small amounts of low molecular weight proanthocyanidins were bound in 2014 and 2015, respectively. Differences in SEC between samples of the two years are greater than those observed with phloroglucinoly-

Table 3 Interaction between commercial seed tannin (CST) and cell wall material (CWM) of different ripening stages in 2014 and 2015: Phloroglucinolysis analysis.

\begin{tabular}{lccc}
\hline Interaction & $\begin{array}{c}\text { Tannin in } \\
\text { solution } \\
\text { (mg/L) }\end{array}$ & mDP $^{\mathrm{a}}$ & $\begin{array}{c}\text { Galloylation } \\
(\%)\end{array}$ \\
\hline CST & $798.4 \mathrm{a}^{\mathrm{b}}$ & $2.04 \mathrm{a}$ & $13.1 \mathrm{a}$ \\
CST + CWM 47 (2014) & $688.4 \mathrm{~b}$ & $1.84 \mathrm{~b}$ & $10.5 \mathrm{~b}$ \\
CST + CWM 58 (2014) & $651.0 \mathrm{C}$ & $1.84 \mathrm{~b}$ & $10.7 \mathrm{~b}$ \\
CST + CWM 66 (2014) & $574.4 \mathrm{~d}$ & $1.80 \mathrm{~b}$ & $10.8 \mathrm{~b}$ \\
Significance & $*$ & $*$ & $*$ \\
CST & $798.4 \mathrm{a}$ & $2.04 \mathrm{a}$ & $13.1 \mathrm{a}$ \\
CST + CWM 26 (2015) & $624.3 \mathrm{~b}$ & $1.90 \mathrm{~b}$ & $11.5 \mathrm{~b}$ \\
CST + CWM 37 (2015) & $634.3 \mathrm{~b}$ & $1.89 \mathrm{~b}$ & $11.4 \mathrm{~b}$ \\
CST + CWM 46 (2015) & $566.3 \mathrm{c}$ & $1.89 \mathrm{~b}$ & $11.2 \mathrm{c}$ \\
Significance & $*$ & $*$ & $*$ \\
\hline
\end{tabular}

${ }^{a} \mathrm{mDP}$, mean degree of polymerization.

${ }^{b}$ Different letters within a column indicate significant differences in each year.

${ }^{\mathrm{c}}$ Asterisks indicate significance at $p<0.05$.

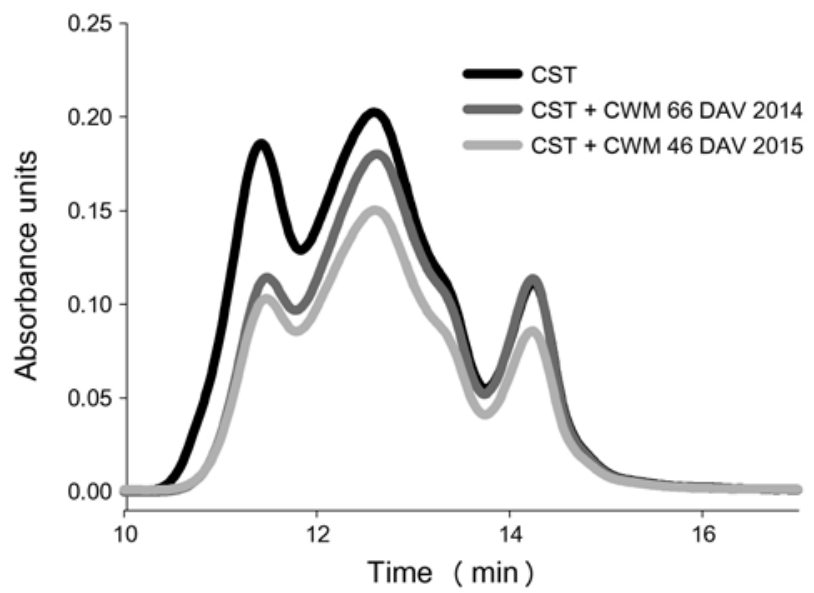

Figure 1 Size exclusion chromatograms of commercial seed tannin (CST) before and after interaction with skin cell wall material (CWM) at harvest in 2014 and 2015. sis analysis: the 2015 samples retained more tannins. These results could be due to the higher maturity level of berries sampled in 2015, since a previous study conducted on Cabernet Sauvignon reported increased affinity of skin CWM for tannins as ripening progressed, even when only minor chemical changes occur in CWM (Bindon et al. 2012). The authors suggested that the increased cell wall porosity during maturation allows incorporation of more tannins. Among these compounds, some could be resistant to phloroglucinol depolymerization (i.e., oxidized tannins), explaining the differences observed between the SEC and phloroglucinolysis analysis.

The reduced concentration of galloylated units noted with phloroglucinolysis seems to be a consequence of the variation in the size of the galloylated form, rather than a specific affinity of the CWM (Bindon et al. 2010b). It is important to note that in red wine, interactions between CWM and tannins could be much more complicated than in model solution, since CWM also binds anthocyanins, subtracting adsorption sites from tannins that become more extractable as a result (Bautista-Ortín et al. 2016a, Bindon et al. 2017). It therefore comes to light that it is very difficult to predict the final concentration of phenolic compounds in wine, since extractability from the skin is influenced by the presence of CWM in the same tissue, and precipitations are caused by the CWM solubilized during vinification (Bindon et al. 2016).

\section{Conclusions}

Variations in anthocyanins during the last 20 days of ripening and changes in skin CWM affinity for tannins could have played an important role in the final phenolic maturity of Merlot grapes. In the two years of study, the concentration of total and extractable anthocyanins that increased until harvest could allow more highly colored wine to be obtained with the progression of ripening, but minor variations of skin and seed tannins provided no information about the modifications of sensory attributes (i.e., reduction in astringency). However, some interesting possibilities were raised from the dynamic affinity of skin CWM for seed tannins. CWM increased adsorption of tannins until harvest and favored adsorption of those forms more involved in the perception of astringency. In other words, the reduction in undesired sensations expected with the progression of ripening could be related to increased affinity of CWM for tannins, particularly in the forms more responsible for these sensations. Following this hypothesis, increasing quantities of astringent and rough tannins could be removed from must or wine by precipitation with CWM. This research gives new insights into the study of phenolic maturity that should be deepened by further investigation, taking into account the role of viticultural variables and enological techniques on the interactions between CWM and tannins.

\section{Literature Cited}

Allegro G, Pastore C, Valentini G, Muzzi E and Filippetti I. 2016. Influence of berry ripeness on accumulation, composition and extractability of skin and seed flavonoids in cv. Sangiovese $(V$. vinifera L.). J Sci Food Agric 96:4553-4559. 
Bautista-Ortín AB, Rodríguez-Rodríguez P, Gil-Muñoz R, JiménezPasqual E, Busse-Valverde N, Martínez-Cutillas A, López-Roca JM and Gómez-Plaza E. 2012. Influence of berry ripeness on concentration, qualitative composition and extractability of grape seed tannins. Aust J Grape Wine Res 18:123-130.

Bautista-Ortín AB, Cano-Lechuga M, Ruiz-García J and GómezPlaza E. 2014. Interactions between grape skin cell wall material and commercial enological tannins. Practical implications. Food Chem 152:558-565.

Bautista-Ortín AB, Ruiz-García Y, Marín F, Molero N, ApolinarValiente R and Gómez-Plaza E. 2015. Remarkable proanthocyanidin adsorption properties of Monastrell pomace cell wall material highlight its potential use as an alternative fining agent in red wine production. J Agric Food Chem 63:620-633.

Bautista-Ortín AB, Martínez-Hernández A, Ruiz-García Y, Gil-Muñoz R and Gómez-Plaza E. 2016a. Anthocyanins influence tannin-cell wall interactions. Food Chem 206:239-248.

Bautista-Ortín AB, Ben Abdallah R, Castro-López L, Jiménez-Martínez MD and Gómez-Plaza E. 2016b. Technological implications of modifying the extent of cell wall-proanthocyanidin interactions using enzymes. Int J Mol Sci 17:E123.

Bindon KA, Smith PA and Kennedy JA. 2010a. Interaction between grape-derived proanthocyanidins and cell wall material. 1. Effect on proanthocyanidin composition and molecular mass. J Agric Food Chem 58:2520-2528.

Bindon KA, Smith PA, Holt H and Kennedy JA. 2010b. Interaction between grape-derived proanthocyanidins and cell wall material. 2 . Implications for vinification. J Agric Food Chem 58:10736-10746.

Bindon KA, Bacic A and Kennedy JA. 2012. Tissue-specific and developmental modifications of grape cell walls influence the adsorption of proanthocyanidins. J Agric Food Chem 60:9249-9260.

Bindon KA, Madani SH, Pendleton P, Smith PA and Kennedy JA. 2014. Factors affecting skin tannin extractability in ripening grapes. J Agric Food Chem 62:1130-1141.

Bindon KA, Li S, Kassara S and Smith PA. 2016. Retention of proanthocyanidin in wine-like solution is conferred by a dynamic interaction between soluble and insoluble grape cell wall components. J Agric Food Chem 64:8406-8419.

Bindon KA, Kassara S and Smith PA. 2017. Towards a model of grape tannin extraction under wine-like conditions: The role of suspended mesocarp material and anthocyanin concentration. Aust J Grape Wine Res 23:22-32.

Bordiga M, Travaglia F, Locatelli M, Coïsson JD and Arlorio M. 2011. Characterisation of polymeric skin and seed proanthocyanidins during ripening in six Vitis vinifera L. cv. Food Chem 127:180-187.

Brunner E, Domhof S and Langer F. 2012. Nonparametric Analysis of Longitudinal Data in Factorial Experiments. pp. 115-116. John Wiley \& Sons Inc., New York.

Cadot Y, Miñana-Castello MT and Chevalier M. 2006. Anatomical, histological, and histochemical changes in grape seeds from Vitis vinifera L. cv. Cabernet franc during fruit development. J Agric Food Chem 54:9206-9215.
Castro-López L, Gómez-Plaza E, Ortega-Regules A, Lozada D and Bautista-Ortín AB. 2016. Role of cell wall deconstructing enzymes in the proanthocyanidin-cell wall adsorption-desorption phenomena. Food Chem 196:526-532.

De Vries JA, Voragen AGJ, Rombouts FM and Pilnik W. 1981. Extraction and purification of pectins from alcohol insoluble solids from ripe and unripe apples. Carbohydr Polym 1:117-127.

Downey MO, Harvey JS and Robinson SP. 2003. Analysis of tannins in seeds and skins of Shiraz grapes throughout berry development. Aust J Grape Wine Res 9:15-27.

Downey MO, Dokoozlian NK and Krstic MP. 2006. Cultural practice and environmental impacts on the flavonoid composition of grapes and wine: A review of recent research. Am J Enol Vitic 57:257-268.

Fournand D, Vicens A, Sidhoum L, Souquet JM, Moutounet M and Cheynier V. 2006. Accumulation and extractability of grape skin tannins and anthocyanins at different advanced physiological stages. J Agric Food Chem 54:7331-7338.

Gatti M, Galbignani M, Garavani A, Bernizzoni F, Tombesi S, Palliotti A and Poni S. 2016. Manipulation of ripening via antitranspirants in cv. Barbera (Vitis vinifera L.). Aust J Grape Wine Res 22:245-255.

Haslam E. 1998. Molecular recognition: Phenols and polyphenols. In Practical Polyphenolics: From Structure to Molecular Recognition and Physiological Action. pp. 138-177. Cambridge University Press, Cambridge, UK.

Hernández-Hierro JM, Quijada-Morín N, Rivas-Gonzalo JC and Escribano-Bailón MT. 2012. Influence of the physiological stage and the content of soluble solids on the anthocyanin extractability of Vitis vinifera L. cv. Tempranillo grapes. Anal Chim Acta 732:26-32.

Kennedy JA and Jones JP. 2001. Analysis of proanthocyanidin cleavage products following acid-catalysis in the presence of excess phloroglucinol. J Agric Food Chem 49:1740-1746.

Kennedy JA and Taylor AW. 2003. Analysis of proanthocyanidins by high-performance gel permeation chromatography. J Chromatogr A 995:99-107.

Le Bourvellec C, Guyot S and Renard CMGC. 2004. Non-covalent interaction between procyanidins and apple cell wall material: Part I. Effect of some environmental parameters. Biochim Biophys Acta 1672:192-202.

Llaudy MC, Canals R, Canals JM and Zamora F. 2008. Influence of ripening stage and maceration length on the contribution of grape skins, seeds and stems to phenolic composition and astringency in wine-simulated macerations. Eur Food Res Technol 226:337-344.

Mattivi F, Guzzon R, Vrhovsek U, Stefanini M and Velasco R. 2006. Metabolite profiling of grape: Flavonols and anthocyanins. J Agric Food Chem 54:7692-7702.

Pastor Del Rio JL and Kennedy JA. 2006. Development of proanthocyanidins in Vitis vinifera L. cv. Pinot noir grapes and extraction into wine. Am J Enol Vitic 57:125-132.

Vidal S, Francis L, Guyot S, Marnet N, Kwiatkowski M, Gawel R, Cheynier V and Waters EJ. 2003. The mouth-feel properties of grape and apple proanthocyanidins in a wine-like medium. J Sci Food Agric 83:564-573. 